ICAMS $2016-6^{\text {th }}$ International Conference on Advanced Materials and Systems

\title{
CHROMIUM REMOVAL FROM THE TANNERY WASTEWATER USING INDIGENOUS ADSORBENT
}

\author{
MD. ABUL HASHEM, MD. SHAHRUK NUR-A-TOMAL, AZIZA AHSAN \\ Khulna University of Engineering \& Technology (KUET), Leather Engineering Department, \\ Khulna-9203,Bangladesh,mahashem96@yahoo.com,mahashem@mail.kuet.ac.bd
}

\begin{abstract}
Tannery is recognized as high-strength waste-generating industry. In tannery, leather processing involves a series of chemical treatments and mechanical operations to attain the prescribed characteristics. Inapt disposal of solid and liquid waste from the tannery cause a serious environmental pollution. Chromium containing wastewater is generated from chrome tanning operation which is the most hazardous pollutants released to the environment. Treatment of highchromium-containing wastewater is a major concern in leather processing. In this study, indigenous adsorbent was investigated to remove the metals, especially chromium from the chrome tanning wastewater. The prepared adsorbent was directly mixed with chrome tanning wastewater. Various parameters such as adsorbent dose and contact time were optimized in batchwise technique. The maximum removal of chromium was attained $99.9 \%$. The use of indigenous adsorbent for the removal of chromium could be better instead of conventional methods.
\end{abstract}

Keywords: tannery, chrome tanning wastewater, indigenous adsorbent.

\section{INTRODUCTION}

Tannery strengthens the economy significantly, though it is facing severe challenges due to its environmental pollution caused by the wastes produced during leather manufacturing. In tannery, leather processing involves a series of chemical treatments and mechanical operations to attain the recommended characteristics. Inapt disposal of wastewater and solid waste from the tannery cause a serious environmental pollution.

During leather processing, huge volume of wastewater is generated. Since soaking to finishing operations, each and every chemical operation generate considerable amount of wastewater. Chromium containing wastewater is generated from chrome tanning operation which is the most hazardous pollutants released to the environment from the tannery. Tanning is the subsequent operation of pickling and is the most common technique in leather processing. In tanning, 90\% tanneries use basic chromium sulfate as tanning agent to obtain better quality leather (Avindhan et al., 2004). The basic chromium sulfate binds with collagen to make it stabilize against biodegradation (Hashem et al., 2015). Averagely, only $60 \%$ of the chromium is up taken by the pickled pelt and $40 \%$ chromium remains in the solid/liquid wastes, especially as spent chrome liquor (Fabiani et al., 1997). In conventional chrome tanning, wastewater contains 1500-3000 mg/L chromium (Suresh et al., 2001).

Discharging of high chromium containing tanning wastewater is a major concern in leather processing. It is also a potential pollutant to soil, water, and air under definite conditions. A fraction of discharged spent chrome liquor is directly mixed with the water body, which causes serious environmental pollution; another fraction of chromium is settled in the lagoon or adsorbed by sediment/soil. Chromium has toxicity to humans at high doses. It exists in several oxidation states, with trivalent chromium and hexavalent chromium species being the most common forms (Kotas and Stasicka, 2000). The occupational exposure of chromium has been widespread and it is shown that chromium (III) under certain ligand conditions in environments leads to cell death 
and structural modification of proteins (Balamurugan et al., 2002). Removal of the chromium present in the wastewater is necessary for human and environmental causes.

In the past few decades, many researches have been carried out to recovery or remove chromium from the tannery wastewater using stone cutting solid waste (AlJabari et al., 2012), bone charcoal (Dahbi et al., 2002), natural marl (Jabari et al., 2009); but most of the techniques approached by treating mixed tannery wastewater. In this study, an approached was made to remove chromium from the chrome tanning wastewater using natural adsorbent. The use of low cost natural products to remove chromium could be preferable instead of conventional methods.

\section{MATERIALS AND METHODS}

\section{Sample Collection}

The chromium containing wastewater was collected from the SAF Leather Industries Ltd., Jessore, Bangladesh. Just after the chrome tanning operation, the wastewater was collected in polyethylene container which was pre-washed with diluted nitric acid, and immediately transported to the laboratory for experimentation. Abundantly available plant seed husk was collected from local area.

\section{Materials}

The reagents perchloric acid (Merck, India), sulphuric acid (Merck KGaA, Germany), nitric acid (Merck KGaA, Germany), ammonium ferrous sulphate (Merck, India), $N$-phenylanthranilic (Loba Chemie, India), glass bed (Loba Chemie, India), and filter paper (Whatman No. 1) were purchased from a local scientific store.

\section{Characterization of Wastewater}

The wastewater was characterized by analysing it for chromium following Society of Leather Technologists and Chemists (1996) official method of analysis (SLC 208). The analysis was done in triplicates, and the mean was used for calculations. $\mathrm{pH}$ meter (UPH-314, USA) was used to measure the $\mathrm{pH}$ of the wastewater. Before measuring the $\mathrm{pH}$, the meter was calibrated with standard solutions.

\section{Adsorbent Preparation}

The plant seed husks were sun dried and stored at room temperature. After drying the samples were burnt at $450-550^{\circ} \mathrm{C}$ and grinded to make powder using a mortar. After shaking on a sieve, the adsorbent with the required size was obtained.

\section{Adsorption Experiments}

The given amount of prepared charcoal was directly mixed with a fixed volume of chrome tanning wastewater. The samples were carefully stirred over a fixed time period, then filtered and the remaining chromium was determined in the solution was determined by following Society of Leather Technologists and Chemists (1996) official method of analysis (SLC 208). 
ICAMS $2016-6^{\text {th }}$ International Conference on Advanced Materials and Systems

\section{Batch Adsorption Experiments}

Various parameters such as adsorbent dose and contact time were optimized in batch-wise technique. The optimized conditions were established by investigating the chromium removal efficiency.

Effect of the Dose of Adsorbent

The chromium removal percentage of the adsorbent is increased as the dose of the adsorbent is increased because of the increase in surface area and metal binding sites. To optimize the dose of adsorbent, varying adsorbent doses were used for each batch 1 , $2,3,4,5,6$, and $7 \mathrm{~g}$, where other parameters were left unchanged, such as contact time (15 $\mathrm{min})$ and initial $\mathrm{pH}(4.0)$.

\section{Effect of Contact Time}

Chromium removal percentage is raised with increasing contact time. When the contact time of the chromium ions and binding sites is extended, the adsorption becomes more effective. To determine optimal contact time, varying stirring time were maintained for each batch $5,10,15,20,25$, and 30 min respectively, while the other parameters remained constant adsorbent $(5 \mathrm{~g})$ and initial $\mathrm{pH}$ (4.0).

\section{RESULTS AND DISCUSSION}

\section{Optimal Adsorbent}

The dose of adsorbent is the most important parameter in the treatment process. The effect of adsorbent dose on the removal efficacy of chromium from wastewater is represented in Fig. 1.

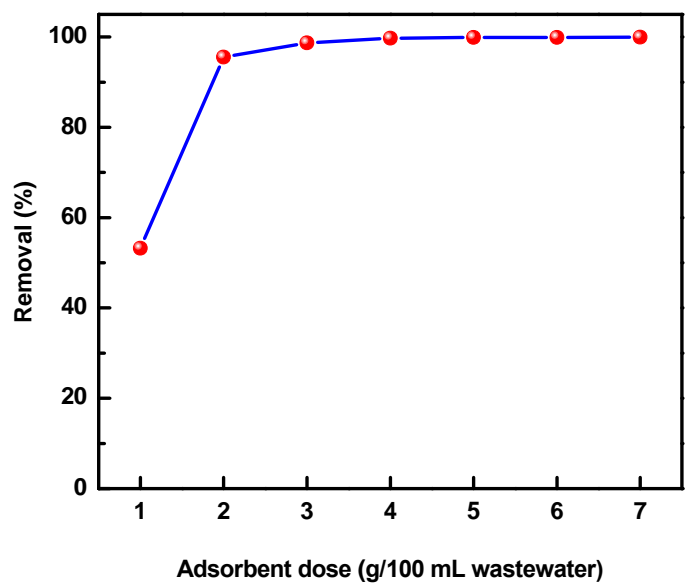

Figure 1. Effect of the dose of adsorbent on the removal of chromium 
The figure clearly indicates that the dose of adsorbent has a significant effect on the removal of chromium. It was perceived that with increasing adsorbent dose, the removal percentage of chromium was increased gradually to $5 \mathrm{~g}$ per $100 \mathrm{~mL}$ wastewater and subsequently with increasing adsorbent dose removal percentage of chromium was increased slightly. The concentration of chromium for the adsorbent dose of $5 \mathrm{~g} / 100 \mathrm{~mL}$ wastewater was $1.9 \mathrm{mg} / \mathrm{L}$; for a dose of $7 \mathrm{~g} / 100 \mathrm{~mL}$ wastewater was $1.4 \mathrm{mg} / \mathrm{L}$. Therefore, $5 \mathrm{~g}$ adsorbent for every $100 \mathrm{~mL}$ wastewater was determined to be the optimal adsorbent dose.

It was perceived that the addition of adsorbent dose increased the $\mathrm{pH}$ of wastewater and adsorbent mixture. As Fig. 2 shows, with the increase of adsorbent dose, there was a gradual increase of the final $\mathrm{pH}$.

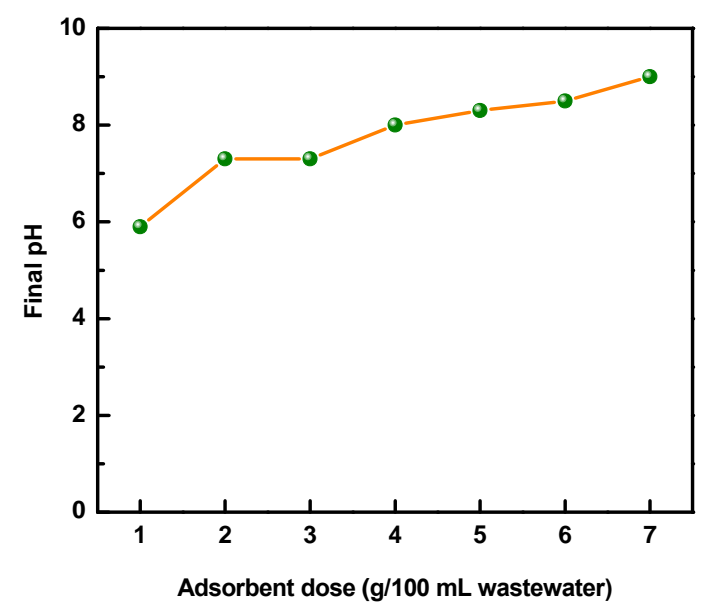

Figure 2. Change of final $\mathrm{pH}$ with different adsorbent dose

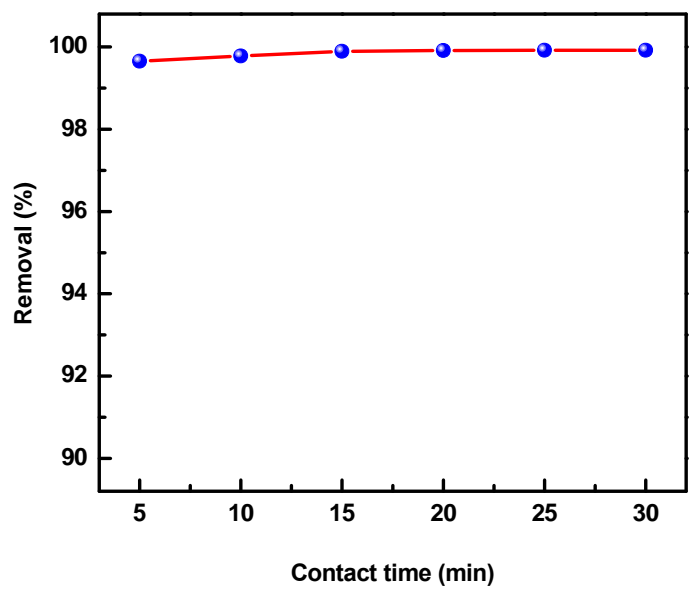

Figure 3. Effect of contact time on the removal of chromium 
ICAMS $2016-6^{\text {th }}$ International Conference on Advanced Materials and Systems

\section{Optimal Contact Time}

Chromium removal efficiency was observed at regular time intervals to determine the optimal contact time. As Fig. 3 shows, with the lapse of time, there was a gradual increase of the chromium removal percentage; at $15 \mathrm{~min}$, the chromium removal efficiency was at its maximum (99.9\%), after which the removal percentage of chromium was increased slightly.

\section{Efficiency of the Treatment Process}

The results of the treatment process with optimum conditions are represented in Table 1. The optimized treatment conditions were: adsorbent dose $5 \mathrm{~g} / 100 \mathrm{~mL}$ wastewater and contact time $15 \mathrm{~min}$. The initial concentration of chrome tanning wastewater was $3581.1 \mathrm{mg} / \mathrm{L}$ and after treatment at optimised conditions concentration was $1.9 \mathrm{mg} / \mathrm{L}$. Therefore, it could be concluded that the maximum removal of chromium was attained $99.9 \%$.

Table 1. Removal of chromium from the wastewater and compare with permissible limit

\begin{tabular}{lccc}
\hline Parameter & Before treatment & After treatment & Permissible limit $\left(\mathrm{MoEF}^{*}, 1997\right)$ \\
\hline Chromium $(\mathrm{mg} / \mathrm{L})$ & 3581.1 & 1.9 & 2.0 \\
$\mathrm{pH}$ & 4.0 & 8.3 & $6.0-9.0$ \\
\hline
\end{tabular}

*MoEF - Ministry of Environment \& Forests

\section{CONCLUSION}

In this study, the most hazardous chrome tanning wastewater of tannery was treated with indigenous adsorbent. The results show excellent chrome removal efficiency (99.9\%) at optimized conditions. The optimized treatment conditions were: adsorbent dose $5 \mathrm{~g} / 100 \mathrm{~mL}$ wastewater and contact time $15 \mathrm{~min}$. Therefore, the use of low cost indigenous adsorbent for the removal of chromium is could be better option.

\section{REFERENCES}

Al-Jabari, M., Abdulfailat, M. and Shaleen, S. (2012), "Treating Leather Tanning Wastewater with Stone Cutting Solid Waste", Clean - Soil, Air, Water, 40(2), 206-210.

Avindhan, R., Madhan, B., Rao, J.R., Nair, B.U. and Amasami T. (2004), "Bioaccumulation of chromium from tannery wastewater: an approach for chrome recovery and reuse", Environmental Science and Technology, 38, 300-306.

Balamurugan, K., Rajaram, R., Ramasami, T. and Narayanan, S. (2002), "Chromium(III) induced apoptosis of lymphocytes: death decision by ROS and Src-family tyrosine kinases", Free Radical Biology and Medicine, 33, 1622-1640.

Dahbi, S., Azzi, M., Saib, N., de la Guardia, M., Faure, R. and Durand, R. (2002), "Removal of trivalent chromium from tannery waste waters using bone charcoal", Analytical and Bioanalytical Chemistry, 374, 540-546.

Fabiani, C., Ruscio, F., Spadoni, M. and Pizzichini, M. (1997), "Chromium(III) salts recovery process from tannery wastewaters", Desalination, 108, 183-191.

Hashem, M.A, Islam, A., Mohsin, S. and Nur-A-Tomal, M.S. (2015), "Green environment suffers by discharging of high-chromium containing wastewater from the tanneries at Hazaribagh, Bangladesh", Sustainable Water Resources Management, 1, 343-347.

Jabari, M., Aqra, F., Shahin, S. and Khatib, A. (2009), "The treatment of chromium tanning wastewater using natural marl", Chemical Speciation \& Bioavailability, 21(3), 185-191.

Kotas, J. and Stasicka, Z. (2000), "Chromium occurrence in the environment and methods of its speciation", Environmental Pollution, 107, 263-283. 


\section{Chromium Removal from the Tannery Wastewater Using Indigenous Adsorbent}

Ministry of Environment and Forests (MoEF) (1997), Environment Conservation Rules, Government of the People's Republic of Bangladesh.

Society of Leather Technologist and Chemists (1996), Official Methods of Analysis, Northampton, UK.

Suresh, V., Kanthimathi, M., Thanikaivelan, P., Rao, J.R. and Nair, B.U. (2001), "An improved productprocess for cleaner chrome tanning in leather processing", Journal of Cleaner Production, 9, 483-491. 